\title{
A Comparison of the Maturation of Greenland Halibut (Reinhardtius hippoglossoides) from Populations Throughout the North Atlantic
}

\author{
M. J. Morgan and W. R. Bowering \\ Dept. of Fisheries and Oceans, P.O. Box 5667, St. John's, NL A1C 5X1, Canada \\ A. C. Gundersen \\ Møre Research, Section of Fisheries, P.O. Box 5075, N-6021 Ålesund, Norway \\ Å. Høines \\ Institute of Marine Research, P.O. Box 1870, Nordnes, N-5817 Bergen, Norway \\ B. Morin \\ Pêches et Océans Canada, CP 1000, Mont-Joli, PQ G5H 3Z4, Canada \\ O. Smirnov \\ Knipovich Polar Research Institute of Marine Fisheries and Oceanography (PINRO) \\ 6 Knipovich Street, Murmansk 183763, Russia \\ and \\ E. Hjörleifsson \\ Marine Research Institute, P.O. Box 1390, Skúlagata 4, IS-121 Reykjavik, Iceland
}

\begin{abstract}
We examined the maturation of Greenland halibut from data collected on four populations: Gulf of St. Lawrence, Labrador-eastern Newfoundland, East Greenland-Iceland-Faroe Islands and the Northeast Arctic (Svalbard and Barents Sea). We compared the maturity schedules among these populations as well as the variability in the data from the different data sets. Estimates of size and age at $50 \%$ maturity were very similar for the different data sets except that the fish in the NAFO Divisions $2 \mathrm{~J}+3 \mathrm{~K}$ portion of the Labrador-eastern Newfoundland area appeared to mature at a considerably larger size and older age. All data sets showed substantial variability with data from the Gulf of St. Lawrence during the 1996 to 2000 period being perhaps the least variable. When data collected over the entire distribution area were compared to data collected from portions of a population's distribution, there was substantially less variability.
\end{abstract}

Key words: age, Greenland halibut, length, maturation, variability

\section{Introduction}

Greenland halibut (Reinhardtius hippoglossoides Walbaum) is a deepwater flatfish species that is distributed throughout the entire rim of the North Atlantic (Bowering and Brodie, 1995; Bowering and Nedreaas, 2000). It has been caught as deep as 2200 m (Boje and Hareide, MS 1993; de Cardenas et al., MS 1996) although it is generally found in highest densities from 500 to $1200 \mathrm{~m}$ and in some areas to $1800 \mathrm{~m}$ (Bowering and Brodie, 1995). Tagging experiments have found movements by this species over extreme distances and there is evidence of extensive gene flow among populations of Greenland halibut in the North Atlantic (Sigurdsson, 1981; Bowering, 1984; Boje MS, 1994; Vis et al., 1997).

There are four main areas of concentration of Greenland halibut in the North Atlantic (Fig. 1). These are in the Gulf of St. Lawrence (NAFO Div. 4RST), off eastern Canada and western Greenland (NAFO Subareas 0, 1, 2 and Div. 3KLMNO), eastern Greenland, Iceland and Faroe Islands (Nordic) population 


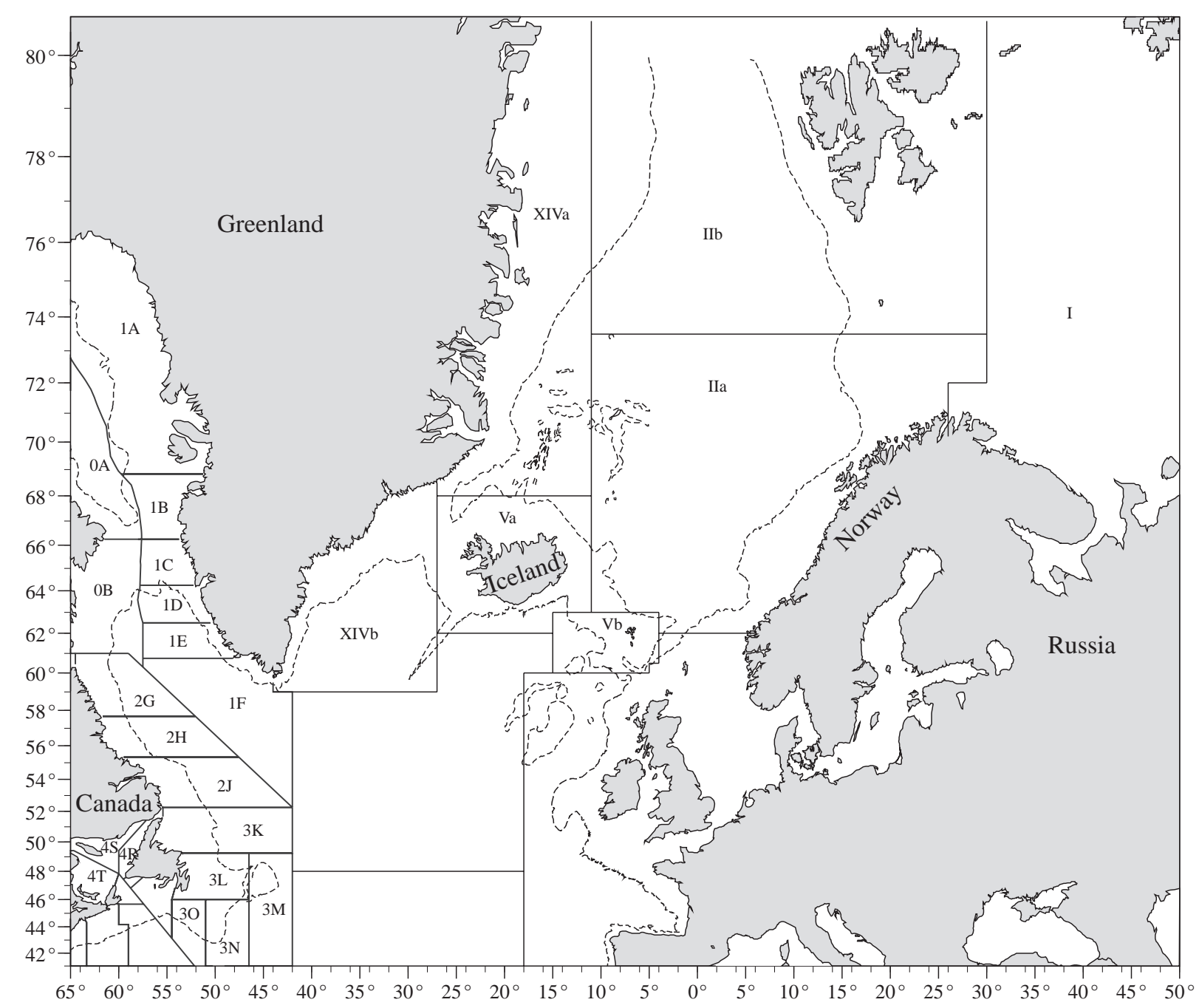

Fig. 1. Map of study area showing the NAFO and ICES Divisions. The $1000 \mathrm{~m}$ depth contour is also shown. See text for details on sampling locations.

(ICES Subareas V and XIV) and the northeastern Arctic population (ICES Subareas I and II). Although considered to be a single population, the Greenland halibut in NAFO Subareas 0, 1, 2 and Div. 3KLMNO in the offshore are managed as two separate stocks: the Davis Strait stock (NAFO Subarea 0 and 1) and the Labrador-eastern Newfoundland stock (Subarea $2+$ Div. 3KLMNO).

Studies on the maturation and spawning of Greenland halibut have revealed a great deal of variability. The proportion of adult fish at size and age has been found to exhibit a high degree of geographic and temporal variation (Junquera, MS 1994; Junquera and Saborido-Rey, MS 1995a; Morgan and Bowering, 1997; Morgan and Bowering, MS 1999). The occur- rence of immature fish at large size also appears to be common (Fedorov, 1971; Jorgensen 1997; Morgan and Bowering, 1997). Greenland halibut appears to have a peak and secondary spawning period with some fish in spawning condition being found in most months (Fedorov, 1971; Junquera, MS 1994; Junquera and Zamarro, 1994). Fedorov (1971) also found that Greenland halibut (at least in the Barents Sea) may skip spawning seasons.

The purpose of this paper is to compare the estimates of maturity from the different populations of Greenland halibut in the North Atlantic. As well, we compare the degree of variability in maturity-at-size (and where possible age) of the data collected on the populations of Greenland halibut. 


\section{Materials and Methods}

Data for comparison were available from 7 sources representing at least some portion of the 4 main populations across the North Atlantic.

Data from the Gulf of St. Lawrence (NAFO Div. 4RST) were available from two sources. Data were collected in January-February of each year from 1978 to 1981 during stratified random surveys using bottom otter trawls. Information on size and age at maturity were gathered. These data were collected throughout the Div. 4RST area to depths of about 500 $\mathrm{m}$, but did not cover the most westerly portion of the area where there are known to be concentrations of Greenland halibut, at least in summer. In addition, data collected during August from 1996 to 2000 were also available, consisting of information on size at maturity only. These latter surveys were stratified random using a bottom otter trawl, and covered most of Div. $4 \mathrm{~S}$ and $4 \mathrm{R}$ and the portion of Div. $4 \mathrm{~T}$ inhabited by Greenland halibut. For purposes of estimating maturity, sampling was divided into three areas of concentration of Greenland halibut. Depths down to approximately $300 \mathrm{~m}$ were sampled.

For the Labrador-eastern Newfoundland population (NAFO Subarea $2+$ Div. 3KLMNO), data on size and age were available from NAFO Div. 2J and $3 \mathrm{~K}$. Data were collected during stratified random surveys using a bottom otter trawl. Surveys were mainly conducted during October-December from 1978 to 2000. These surveys were conducted throughout the Div. $2 \mathrm{~J}+3 \mathrm{~K}$ area to a depth of $1000 \mathrm{~m}$ for most of the time series, but since 1995 have been conducted to $1500 \mathrm{~m}$.

For the eastern Greenland-Iceland-Faroe Islands population (ICES Subareas V and XIV) data were available from only the eastern Greenland (ICES Div. $\mathrm{XIVb}$ ) and Iceland (ICES Div. Va) areas of the population's distribution. Data were collected in eastern Greenland from 1995 to 1998 and in 2000 using a variety of gear types. In 1995, gillnets were used, (depth range 800-1 $600 \mathrm{~m}$ ), in 1996 and 1997 data were examined from longline samples (depth range $1200-1400 \mathrm{~m}$ ) and in 1998 and 2000 data were collected using bottom otter trawl (depth range 500-1 $000 \mathrm{~m}$ ). Data were size based only and were collected during July-August from the commercial fishery within an area bounded by $62^{\circ} \mathrm{N}, 42^{\circ} \mathrm{W}$ and $65^{\circ} 30^{\prime} \mathrm{N}$, $32^{\circ} \mathrm{W}$. From Iceland, data on maturity-at-size were available from 1996-2000. The data were collected during surveys combining fixed station and stratified random sampling conducted during October with bottom otter trawl. Depths down to approximately 1200 $\mathrm{m}$ were surveyed throughout the Div. Va area.

Data from the northeastern Arctic population (ICES Subareas I and II) were also available from two sources. Data were available from Russian stratified random surveys of ICES Subarea II portion of the population's distribution using bottom otter trawls conducted during September-December (1984 to 1989 ) and October-December (1990 to 2000). From these sources data were available on maturation at both size and age, except for 2000 when only data on size were available. This survey covers depths from 50 to $900 \mathrm{~m}$ from west of Spitzbergen to $80^{\circ} \mathrm{N}$, south to $71^{\circ} \mathrm{N}$ to just east of the border between Div. II and Div. I. This data set is referred to as 'II Russia'. Data from ICES Subarea II portion of the north-eastern Arctic population were also available from 1996 to 2000 from sampling conducted during July to September by Norway. This survey is conducted with bottom otter trawl and is a combination of stratified random and fixed stations. Data were available for both size and age and this data set will be referred to as 'II Norway'. These data were collected from Spitzbergen in the north, south to $68^{\circ} 30^{\prime} \mathrm{N}$ along the coast of Norway over a depth range of 500-800 m.

In all data sets maturity was determined by macroscopic examination of the gonads although the exact classification varied. The data set for the Gulf of St. Lawrence from 1978 to 1981 and the data from Div. $2 \mathrm{~J}+3 \mathrm{~K}$ were gathered using the classification of Templeman et al. (1978). Data collected from the Gulf of St. Lawrence from 1996 to 2000 used the classification found in Morin and Bernier (MS 1999). For data collected from eastern Greenland and Norway the classifications of Nielsen and Boje (MS 1995) and Fotland et al. (1997) were used. Icelandic data were classified in a manner similar to that described in Fotland et al. (1997) while data collected by Russia were classified according to Sorokin and Grigorjev (1968) and Fedorov (1968). Fish were divided into juveniles and adults and any fish where this determination was considered uncertain were removed from the data sets. Data were available for both males and females in all cases. The timing of the data collection relative to the time of spawning, as well as the area of coverage relative to the area of distribution of the population varied across data sets (Table 1).

Estimated proportion mature-at-size and age, as well as size $\left(L_{50}\right)$ and age $\left(A_{50}\right)$ at $50 \%$ maturity were 
TABLE 1. Survey timing and coverage for each data source.

\begin{tabular}{|c|c|c|c|}
\hline Data Source & Survey Time & Spawning Time & Survey Coverage Relative to Population Distribution \\
\hline Gulf 1978-1981 & January-February & January-March & $\begin{array}{l}\text { Not known precisely. Did not cover most western } \\
\text { portion of summer distribution but unknown if fish a r e } \\
\text { in this area in winter. }\end{array}$ \\
\hline Gulf 1996-2000 & August & January-March & Covers most of the distribution. \\
\hline $\begin{array}{l}\text { Labrador-eastern } \\
\text { Newfoundland }\end{array}$ & October-December & $\begin{array}{l}\text { December-April in } \\
\text { north. August in south. } \\
\text { Evidence of some } \\
\text { spawning year round. }\end{array}$ & $\begin{array}{l}\text { Covers only the NAFO Div. } 2 \mathrm{~J}+3 \mathrm{~K} \text { portion of the } \\
\text { Subarea } 2+\text { Div. } 3 \mathrm{KLMNO} \text { stock area. }\end{array}$ \\
\hline $\begin{array}{l}\text { Eastern } \\
\text { Greenland }\end{array}$ & July-August & Summer (August) & $\begin{array}{l}\text { Covers only part of the ICES Div. XIVb portion of } \\
\text { the Subarea XIV + V stock area. Juveniles may be } \\
\text { particularly lacking in the survey area. }\end{array}$ \\
\hline Iceland & October & $\begin{array}{l}\text { January-March } \\
\text { Evidence of some } \\
\text { spawning year round. }\end{array}$ & $\begin{array}{l}\text { Covers only the ICES Div. Va portion of the } \\
\text { Subarea XIV + V stock area. Covers most of the } \\
\text { distribution in Icelandic waters except for depths } \\
\text { greater than } 1200 \mathrm{~m} \text { off west Iceland. }\end{array}$ \\
\hline II Norway & July-September & $\begin{array}{l}\text { November-January } \\
\text { Evidence of some } \\
\text { spawning year round. }\end{array}$ & $\begin{array}{l}\text { Covers only part of the ICES Subarea II portion of } \\
\text { the Subarea I + II stock area. Covers most of the } \\
\text { distribution in Norwegian waters. }\end{array}$ \\
\hline II Russia & $\begin{array}{l}\text { September-December } \\
\text { 1984-1989. } \\
\text { October-December } \\
\text { 1990-2000. }\end{array}$ & $\begin{array}{l}\text { November-January } \\
\text { Evidence of some } \\
\text { spawning year round. }\end{array}$ & $\begin{array}{l}\text { Covers main spawning grounds and main area of } \\
\text { fishable stock but does not cover nursery areas except } \\
\text { in the last } 2 \text { years. Does not extend southward along } \\
\text { the Norwegian coast. }\end{array}$ \\
\hline
\end{tabular}

determined using probit analyses with a binomial error structure and a logit link function (SAS Institute Inc., 1989). Each data set was tested for significant annual variation using generalized linear models with a logit link function and binomial error structure (McCullagh and Nelder, 1983; SAS Institute Inc., 1993).

The variability of each data set was determined in a number of ways in addition to testing for significant annual variation. Each time series of $L_{50}$ and $A_{50}$ was examined to determine the range in values over the time series. As well, the largest change between two adjacent years was determined. The percentage of years where there was not a significant fit of the model to the data was determined. Finally, for data sets on length at maturity, the observed and predicted proportion mature for selected years was plotted.

For Labrador-eastern Newfoundland and Gulf of St. Lawrence, data exist for both a portion of the stock area and the whole stock area. This allowed a comparison of the variability of estimates using data from only a portion of the stock area with estimates from the whole area. For Labrador-eastern Newfoundland during 1996-1999 'synoptic' surveys were conducted over the whole NAFO Subarea $2+$ Div. 3KLMNO area. Estimates of maturity-at-age and size from the synoptic surveys were compared for those years to estimates from the Div. 2J+3K area only. The 19962000 surveys in the Gulf of St. Lawrence covered most if not all of the stock area but data were collected based on three Subareas: western Gulf, North Anticosti and Esquiman Channel. The only exception was that the Esquiman Area was not sampled in 1998. Estimates of maturity-at-size from each of these Subareas were compared to estimates from the whole Gulf.

\section{Results}

Length at $50 \%$ maturity $\left(L_{50}\right)$ was quite similar for all the data sets except for the NAFO Div. $2 J+3 \mathrm{~K}$ portion of the Labrador-eastern Newfoundland stock area, which was greater than the others for both males and females (Fig. 2, Table 2). Except for Div. 2J+3K, $L_{50}$ was generally less than $50 \mathrm{~cm}$ for males and less than $65 \mathrm{~cm}$ for females. Average $L_{50}$ for both sexes was 


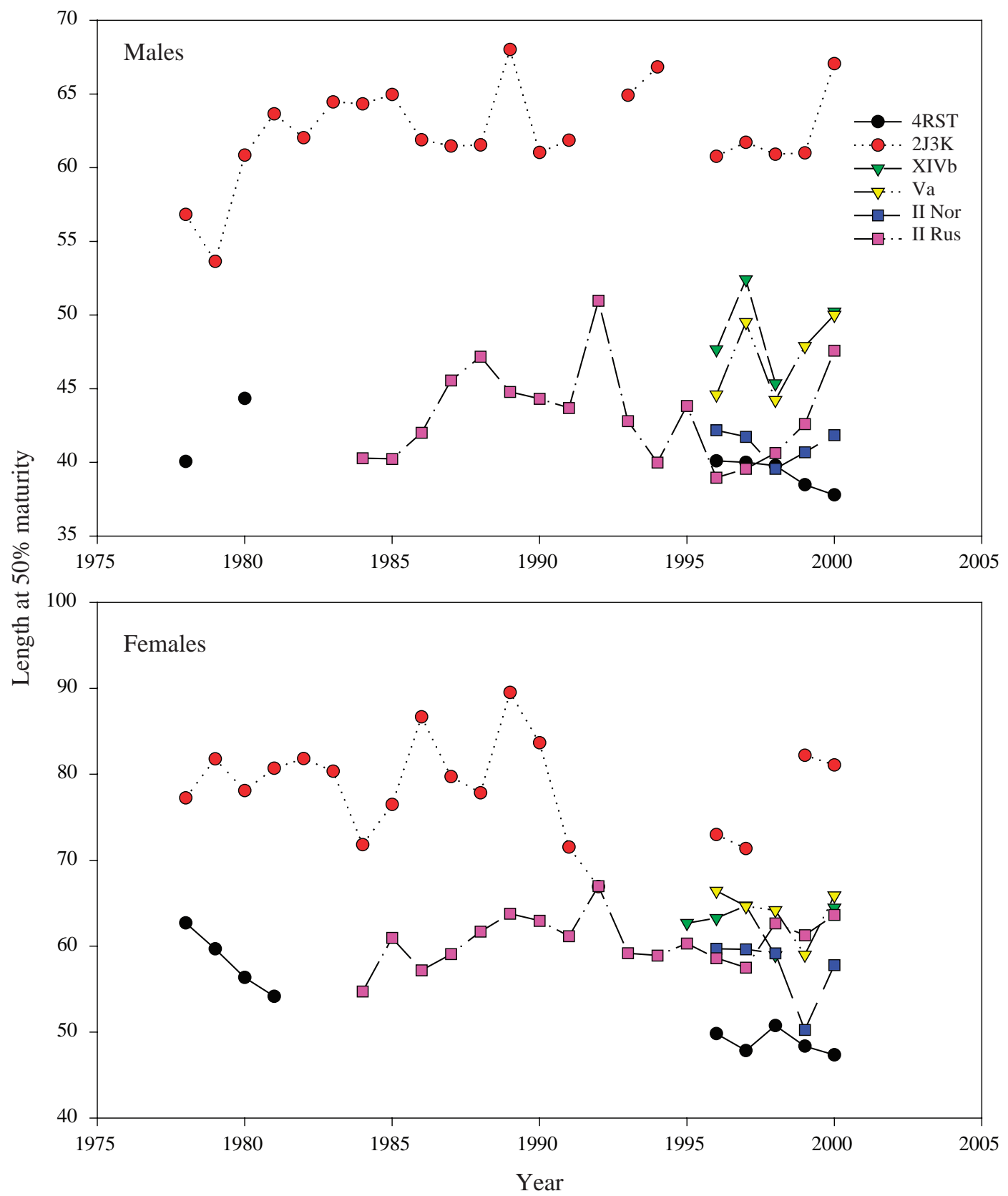

Fig. 2. Length at $50 \%$ maturity for male and female Greenland halibut from the Gulf of St. Lawrence (4RST), Labrador-eastern Newfoundland $(2 \mathrm{~J}+3 \mathrm{~K})$, eastern Greenland (XIVb), Iceland (Va), northeastern Arctic collected by Norway (II Nor) and northeastern Arctic collected by Russia (II Rus).

lowest for the Gulf 1996-2000. For males average $L_{50}$ ranged from 39 to $62 \mathrm{~cm}$ and for females average $L_{50}$ ranged from 48 to $79 \mathrm{~cm}$. There was little indication of trends over time in any of the time series except for males in the Gulf 1996-2000 and females in the Gulf 1978-1981, which both showed a decline in $L_{50}$.
Age at $50 \%$ maturity $\left(A_{50}\right)$ was also very similar for all the data sources except for Div. $2 \mathrm{~J}+3 \mathrm{~K}$, which was greater (Fig. 3, Table 2). There was little indication of trends over the time periods in any of the time series except for females in the Gulf 1978-1981, which showed a decline in $A_{50}$. On average, $A_{50}$ ranged 
TABLE 2. Average length and age at 50\% maturity from each data source.

\begin{tabular}{lcccc}
\hline \hline Data Source & \multicolumn{2}{c}{ Male } & \multicolumn{2}{c}{ Female } \\
& $L_{50}$ & $A_{50}$ & $L_{50}$ & $A_{50}$ \\
\hline Gulf 1978-1981 & 42.20 & 5.34 & 58.22 & 8.23 \\
Gulf 1996-2000 & 39.23 & & 48.22 & \\
Labrador-eastern Newfoundland & 62.37 & 9.78 & 78.54 & 12.78 \\
Eastern Greenland & 48.91 & & 62.79 & \\
Iceland & 47.24 & & 64.01 & \\
II Norway & 41.20 & 4.74 & 57.30 & 8.47 \\
II Russia & 43.29 & 4.81 & 60.61 & 8.13 \\
\hline
\end{tabular}
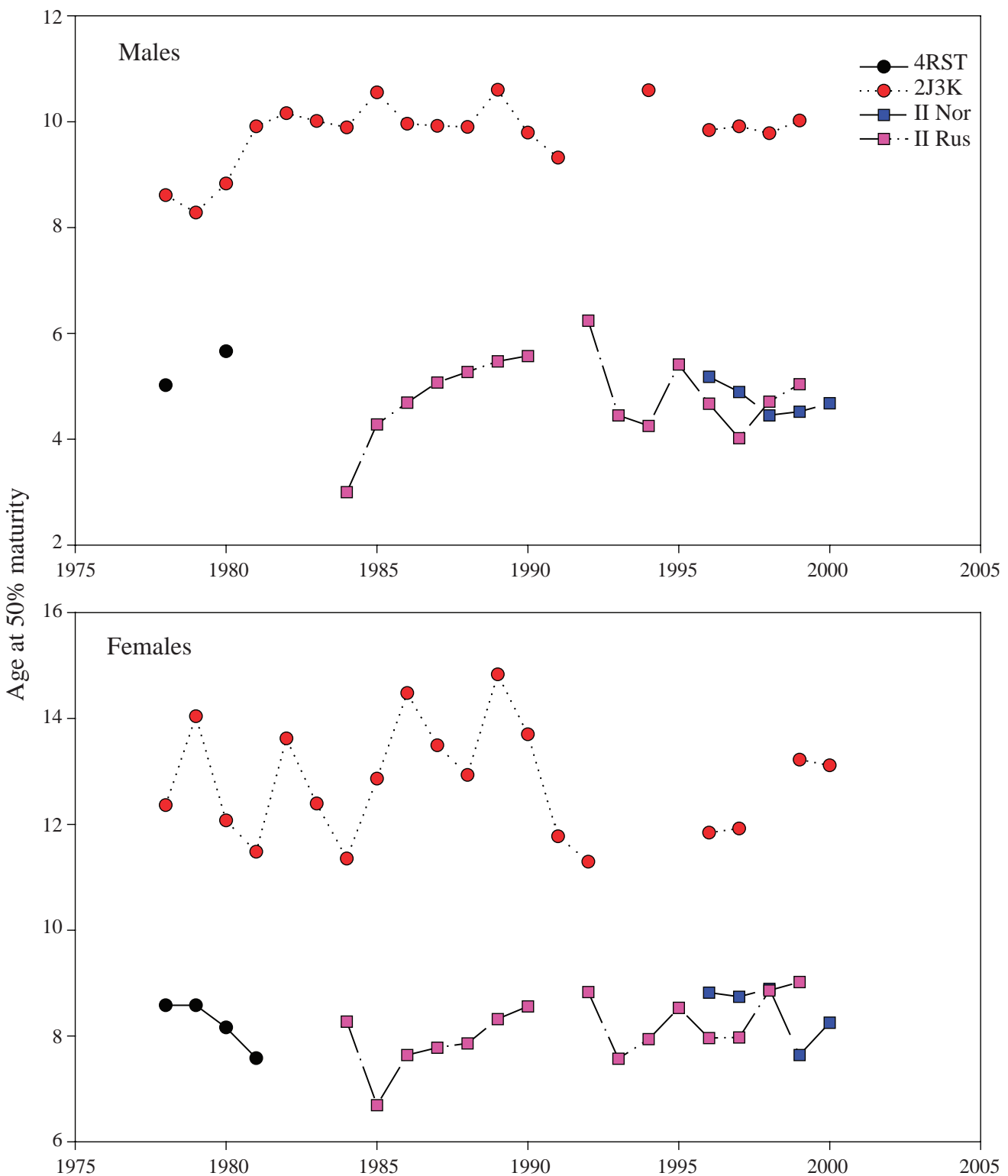

Fig. 3. Age at $50 \%$ maturity for male and female Greenland halibut from the Gulf of St. Lawrence (4RST), Labrador-eastern Newfoundland $(2 \mathrm{~J}+3 \mathrm{~K})$, northeastern Arctic collected by Norway (II Nor) and northeastern Arctic collected by Russia (II Rus). 
from about 5 to almost 10 years for males and from 8 to almost 13 years for females.

Despite few trends in the data, all data sets had significant annual variation in proportion mature-atlength for both males and females (Table 3). There was also significant annual variation in proportion mature-at-age for all data sets except for females from Subarea II Norway, which exhibited no significant interannual variability.

There was no clear indication from other metrics of variability as to which of the data sets (if any) was the most variable (Tables 4 and 5). The largest range in $L_{50}$ for both males and females was Div. $2 \mathrm{~J}+3 \mathrm{~K}$ while the largest annual change was for Div. $2 \mathrm{~J}+3 \mathrm{~K}$ for females and Subarea II Russia for males. The Gulf 1978-1981 and eastern Greenland had the largest percentage of years with a non-significant model fit for males for proportion mature-at-length. (For eastern Greenland the poor model fit for males may be partly due to the use of gillnets which catch few males.) The largest range in $A_{50}$ was found in Subarea II Russia for males and Div. $2 \mathrm{~J}+3 \mathrm{~K}$ for females. These two data sets also had the largest difference between years in $A_{50}$. The Gulf 1978-1981 and Div. 2J+3K had the largest percentage of years with non-significant model fit for maturity-at-age for males and females, respectively. Based on these results none of the data sets is clearly more variable than the others. The Gulf 1996-2000 data set is perhaps the least variable with the smallest range in $L_{50}$, the smallest maximum annual change and no years in which the model did not fit the data.

Observed and predicted proportion mature-atlength is presented for selected years for males in Fig. 4 and females in Fig. 5. All data sources show a large degree of interannual variability. Almost all of the data sets have years where some observations at larger sizes show a lower proportion mature than at smaller sizes. Most have years (particularly among males) where the estimated curve is incomplete. There were cases where there were very few sampled lengthclasses where all fish were observed to be juveniles (e.g. Fig. 4 Subarea II Russia 1984) and cases where no sampled length-classes were observed to be $100 \%$ mature (e.g. Fig. 5 Div. 2J+3K 2000).

When estimates of $L_{50}$ and $A_{50}$ from the synoptic surveys of the entire NAFO Subarea $2+$ Div. $3 \mathrm{KLMNO}$ area are compared to those from the Div. $2 \mathrm{~J}+3 \mathrm{~K}$ area only, the estimates from the entire area have much smaller fiducial limits indicating much better model fit and lower within year variability (Fig. 6). In all years there was a significant fit of the model to the data for the entire area, but for the Div. $2 \mathrm{~J}+3 \mathrm{~K}$ portion the model did not fit the data for females for

TABLE 3. Results of generalized linear analyses of year effect on proportion mature-at-age and size.

\begin{tabular}{|c|c|c|c|}
\hline Data Source & & Length & Age \\
\hline Gulf 1978-1981 & $\begin{array}{l}\text { Male } \\
\text { Female }\end{array}$ & $\begin{array}{l}\text { insufficient data } \\
\chi^{2}=111.9, \mathrm{df}=3, p<0.0001\end{array}$ & $\begin{array}{l}\text { insufficient data } \\
\chi^{2}=39.7, \mathrm{df}=3, p<0.0001\end{array}$ \\
\hline Gulf 1996-2000 & $\begin{array}{l}\text { Male } \\
\text { Female }\end{array}$ & $\begin{array}{l}\chi^{2}=66.4, \mathrm{df}=4, p<0.0001 \\
\chi^{2}=76.3, \mathrm{df}=4, p<0.0001\end{array}$ & \\
\hline $\begin{array}{l}\text { Labrador-eastern } \\
\text { Newfoundland }\end{array}$ & $\begin{array}{l}\text { Male } \\
\text { Female }\end{array}$ & $\begin{array}{l}\chi^{2}=702.4, \mathrm{df}=20, p<0.0001 \\
\chi^{2}=438.2, \mathrm{df}=18, p<0.0001\end{array}$ & $\begin{array}{l}\chi^{2}=575.3, \mathrm{df}=20, p<0.001 \\
\chi^{2}=442.5, \mathrm{df}=18, p<0.001\end{array}$ \\
\hline Eastern Greenland & $\begin{array}{l}\text { Male } \\
\text { Female }\end{array}$ & $\begin{array}{l}\chi^{2}=135.8, \mathrm{df}=3, p<0.0001 \\
\chi^{2}=129.3, \mathrm{df}=5, p<0.0001\end{array}$ & \\
\hline Iceland & $\begin{array}{l}\text { Male } \\
\text { Female }\end{array}$ & $\begin{array}{l}\chi^{2}=123.1, \mathrm{df}=4, p<0.0001 \\
\chi^{2}=502.1, \mathrm{df}=4, p<0.0001\end{array}$ & \\
\hline II Norway & $\begin{array}{l}\text { Male } \\
\text { Female }\end{array}$ & $\begin{array}{l}\chi^{2}=20.6, \mathrm{df}=4, p<0.0005 \\
\chi^{2}=250.4, \mathrm{df}=4, p<0.0001\end{array}$ & $\begin{array}{l}\chi^{2}=11.9, \mathrm{df}=4, p<0.05 \\
\chi^{2}=5.0, \mathrm{df}=4, \mathrm{NS}\end{array}$ \\
\hline II Russia & $\begin{array}{l}\text { Male } \\
\text { Female }\end{array}$ & $\begin{array}{l}\chi^{2}=496.1, \mathrm{df}=16, p<0.0001 \\
\chi^{2}=393.8, \mathrm{df}=16, p<0.0001\end{array}$ & $\begin{array}{l}\chi^{2}=78.5, \mathrm{df}=14, p<0.0001 \\
\chi^{2}=480.9, \mathrm{df}=14, p<0.0001\end{array}$ \\
\hline
\end{tabular}


TABLE 4. Metrics of variability for proportion mature-at-length.

\begin{tabular}{|c|c|c|c|c|}
\hline Data Source & Range in $L_{50}$ & $\begin{array}{c}\text { Maximum } \\
\text { annual change }\end{array}$ & $\begin{array}{c}\text { Percent years } \\
\text { with NS fit }\end{array}$ & Trend \\
\hline \multicolumn{5}{|c|}{ Male } \\
\hline Gulf 1978-1981 & 3.73 & - & 50 & unknown \\
\hline Gulf 1996-2000 & 2.30 & 1.30 & 0 & yes \\
\hline \multicolumn{5}{|l|}{ Labrador- } \\
\hline eastern Newfoundland & 14.38 & 7.20 & 8.7 & no \\
\hline Eastern Greenland & 7.05 & 7.06 & 20 & no \\
\hline Iceland & 5.78 & 5.29 & 0 & no \\
\hline II Norway & 2.62 & 2.17 & 0 & no \\
\hline II Russia & 12.02 & 7.60 & 0 & no \\
\hline \multicolumn{5}{|c|}{ Female } \\
\hline Gulf 1978-1981 & 8.53 & 3.30 & 0 & yes \\
\hline Gulf 1996-2000 & 3.40 & 2.90 & 0 & no \\
\hline \multicolumn{5}{|l|}{ Labrador- } \\
\hline eastern Newfoundland & 22.60 & 12.14 & 17.4 & no \\
\hline Eastern Greenland & 5.75 & 5.75 & 0 & no \\
\hline Iceland & 7.44 & 6.89 & 0 & no \\
\hline II Norway & 9.44 & 8.91 & 0 & no \\
\hline II Russia & 12.26 & 7.81 & 0 & no \\
\hline
\end{tabular}

TABLE 5. Metrics of variablity for proportion mature-at-age.

\begin{tabular}{|c|c|c|c|c|}
\hline Data Source & Range in $A_{50}$ & $\begin{array}{l}\text { Maximum } \\
\text { annual change }\end{array}$ & $\begin{array}{l}\text { Percent years } \\
\text { with NS fit }\end{array}$ & Trend \\
\hline \multicolumn{5}{|c|}{ Male } \\
\hline Gulf 1978-1981 & 0.64 & - & 50 & unknown \\
\hline $\begin{array}{l}\text { Labrador- } \\
\text { eastern Newfoundland }\end{array}$ & 2.32 & 1.08 & 17.4 & no \\
\hline II Norway & 0.73 & 0.44 & 0 & no \\
\hline II Russia & 3.24 & 1.79 & 0 & no \\
\hline \multicolumn{5}{|c|}{ Female } \\
\hline Gulf 1978-1981 & 1.00 & 0.58 & 0 & yes \\
\hline $\begin{array}{l}\text { Labrador- } \\
\text { eastern Newfoundland }\end{array}$ & 3.54 & 2.14 & 17.4 & no \\
\hline II Norway & 1.25 & 1.25 & 0 & no \\
\hline II Russia & 2.33 & 1.58 & 0 & no \\
\hline
\end{tabular}

either length or age in 1998. The interannual variability appeared to be similar between the two data sets.

Estimates from the western Gulf Subarea match the total Gulf fairly closely. This is perhaps not too surprising since this area constituted the bulk of the sampling in each year. For the two other Subareas of the Gulf the fiducial limits were much wider than those for the estimates from the entire Gulf (Fig. 7). As well, estimates from these Subareas generally showed more variation from year to year than those from the entire Gulf. There was a significant fit of the model to the data for all years for the entire Gulf but no significant fit for females in the Esquiman Area in 1999 . 

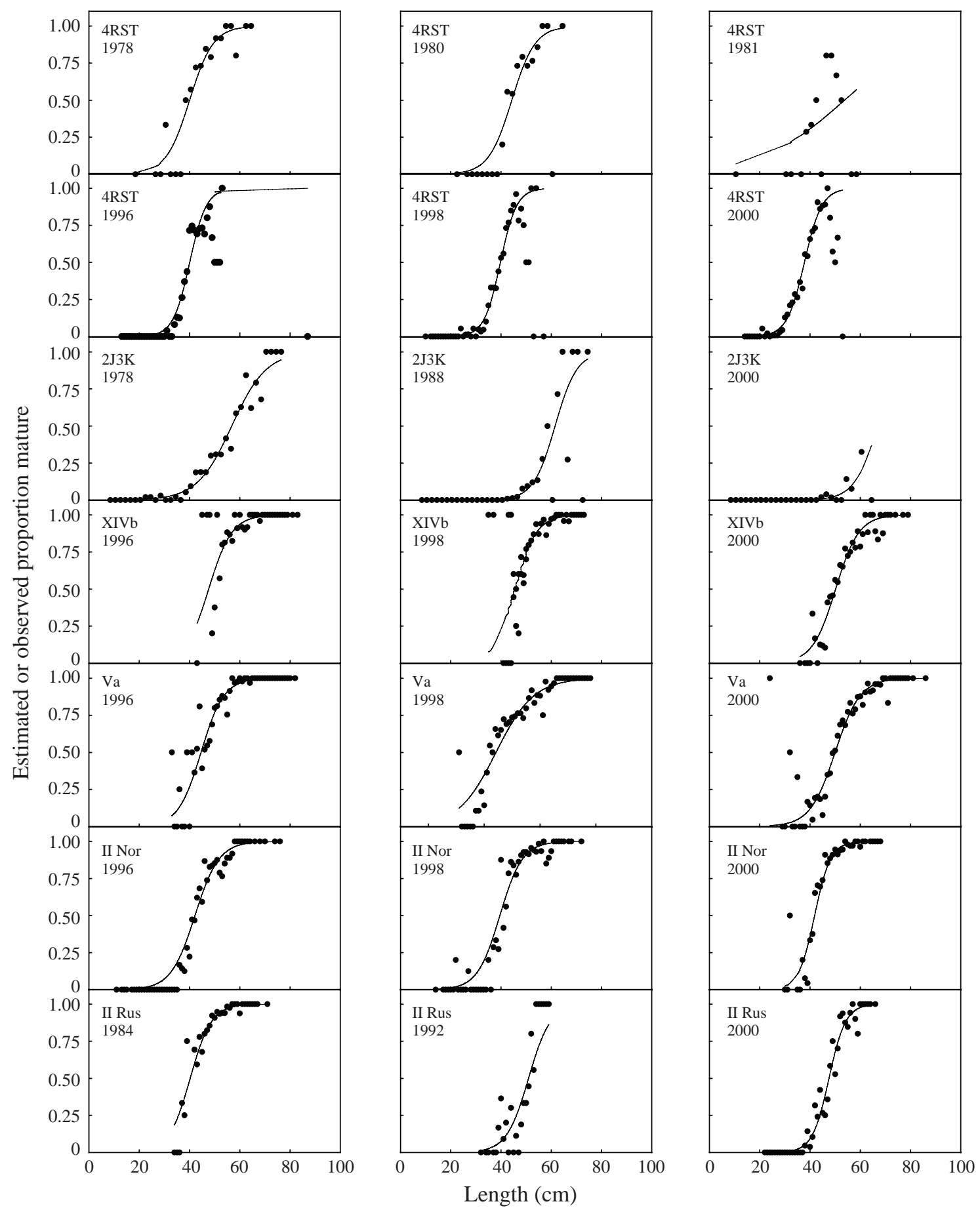

Fig. 4. Estimated and observed proportion mature at length for male Greenland halibut from the Gulf of St. Lawrence (4RST), Labrador-eastern Newfoundland (2J+3K), eastern Greenland (XIVb), Iceland (Va), northeastern Arctic collected by Norway (II Nor) and northeastern Arctic collected by Russia (II Rus). Only selected years are shown. 

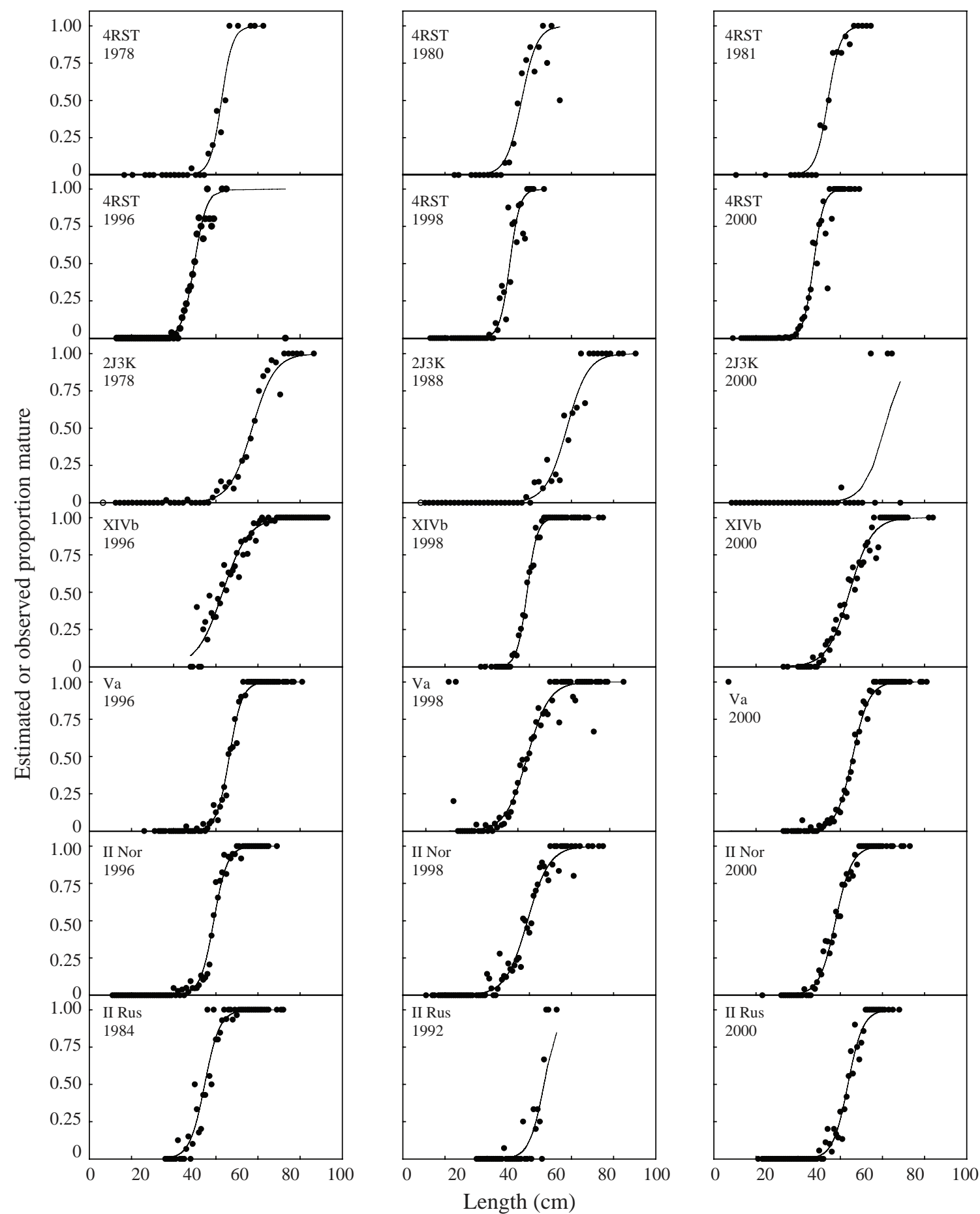

Fig. 5. Estimated and observed proportion mature at length for female Greenland halibut from the Gulf of St. Lawrence (4RST), Labrador-eastern Newfoundland ( $2 \mathrm{~J}+3 \mathrm{~K})$, eastern Greenland (XIVb), Iceland (Va), northeastern Arctic collected by Norway (II Nor) and northeastern Arctic collected by Russia (II Rus). Only selected years are shown. 

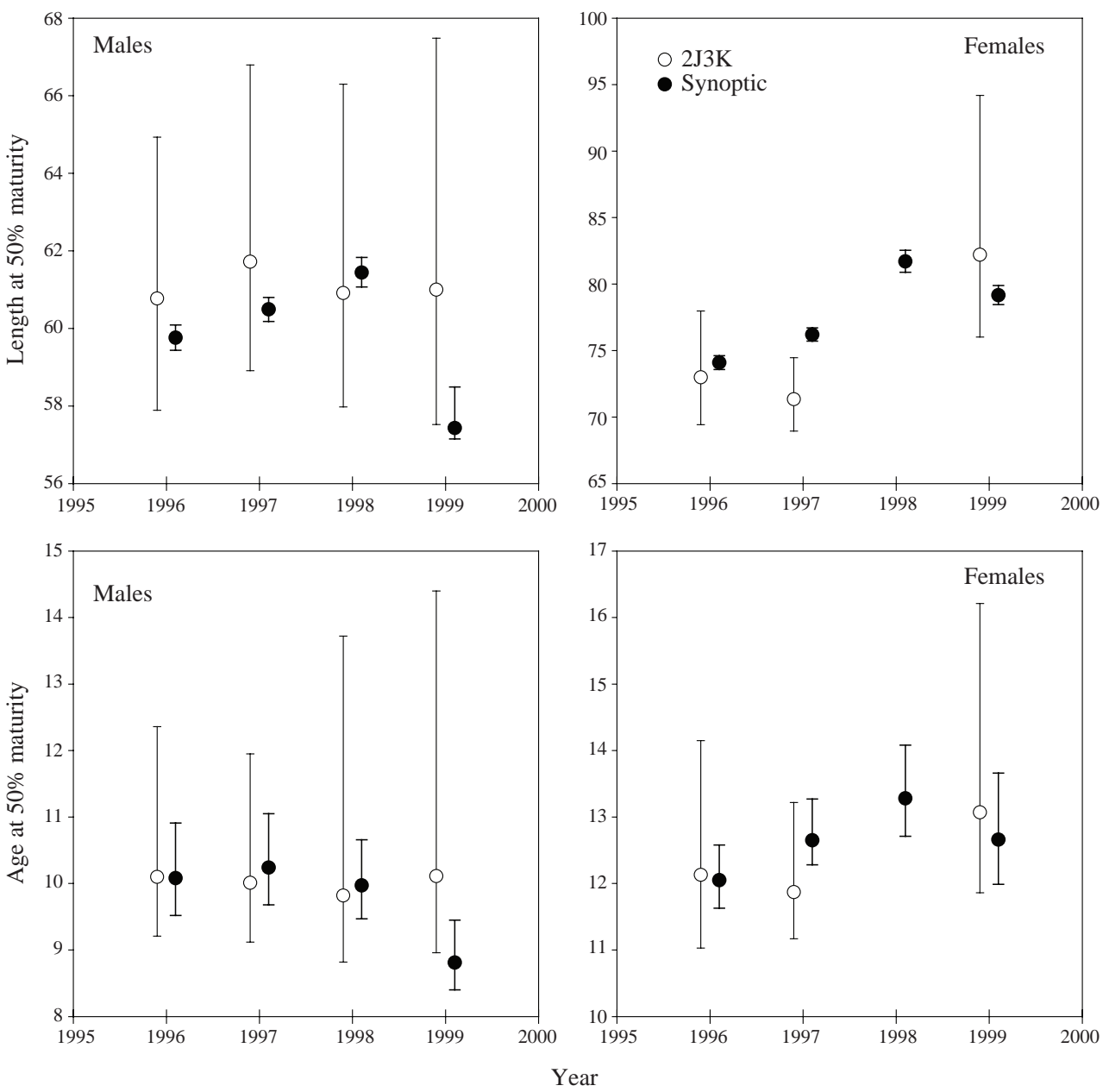

Fig. 6. Length and age at $50 \%$ maturity ( $\pm 95 \%$ fiducial limits) for male and female Greenland halibut from the entire Labrador-eastern Newfoundland area of distribution (synoptic) and from the Div. $2 \mathrm{~J}+3 \mathrm{~K}$ portion of the area only.

\section{Discussion}

Estimates of age and size at $50 \%$ maturity were fairly similar across data sets with the exception of those for the Div. $2 \mathrm{~J}+3 \mathrm{~K}$ portion of the Labradoreastern Newfoundland population, which were much higher. The similarity in maturation across areas is perhaps not surprising given evidence of gene flow between populations (Vis et al., 1997). It is not known why the estimates for Div. $2 \mathrm{~J}+3 \mathrm{~K}$ were higher than for the other populations. Estimates from other studies in regions nearby Div. $2 \mathrm{~J}+3 \mathrm{~K}$ have also produced lower estimates. Junquera et al. (1999) produced estimates of $L_{50}$ for females of $65-70 \mathrm{~cm}$ for the Labrador-eastern Newfoundland population using data collected from NAFO Div. 3LMN. There have been a number of studies in recent years from the Davis Strait/Western Greenland area (NAFO Div. 0B and $1 \mathrm{CD})$ to the north of Div. $2 \mathrm{~J}+3 \mathrm{~K}$. Estimates of $L_{50}$ from these studies have varied from 55 to $69 \mathrm{~cm}$ for females (Jorgensen and Boje, MS 1994; Morgan and Bowering, 1997; Jorgensen, MS 1998). Neither the depth sampled nor the maximum length of fish sampled seems to be a factor in these differences. The study by Junquera et al. (1999) included sampling from most months in each year but the studies from Davis Strait/Western Greenland did not. Although the age and size at maturity determined here for Div. $2 \mathrm{~J}+3 \mathrm{~K}$ are higher than estimates from other areas during the same time period, they are not unique. Earlier estimates of the northeastern Arctic area from Russian surveys in the 1940s and 1960s were very similar (Kovtsova and Nizovtsev, MS 1985) to those from the Div. $2 \mathrm{~J}+3 \mathrm{~K}$ estimates reported here, as are some estimates from early studies in western Greenland (Smidt, 1969). The reasons for this temporal pattern are again, unknown. 


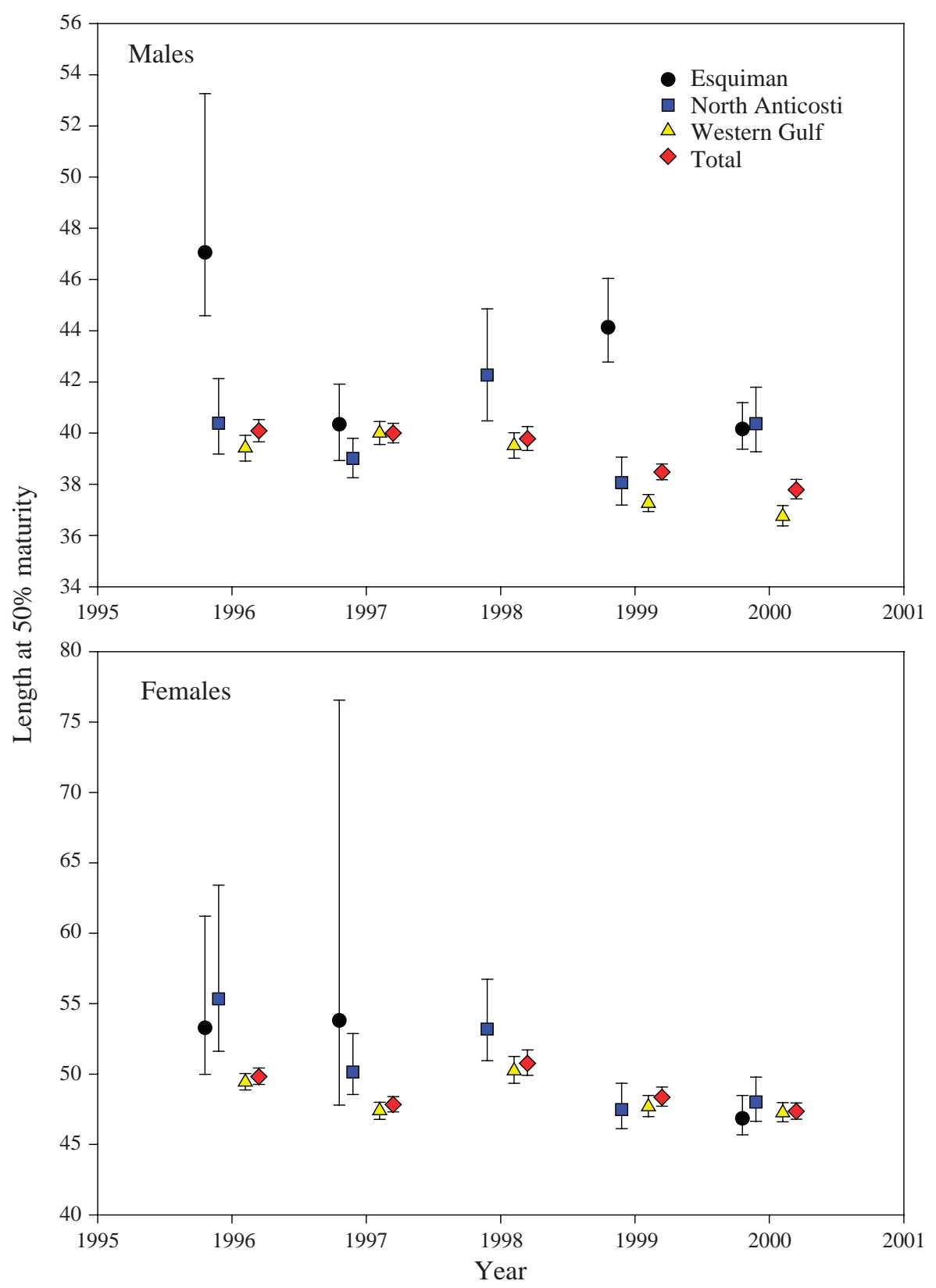

Fig. 7. Length at $50 \%$ maturity ( $\pm 95 \%$ fiducial limits) for male and female Greenland halibut from the entire Gulf of St. Lawrence (total) and from three Subareas (Esquiman, North Anticosti, and Western Gulf).

Variability in maturity estimates appears to be a feature common to all of the data examined here with the Gulf of St. Lawrence 1996-2000 data set being perhaps the least variable. Of the surveys examined here, only that one covers the entire distribution of the stock being examined (see Table 1). Failure to collect data over the full area of distribution of the population may be part of the reason for the variabil- ity in estimates of maturation seen in this study. In order for lack of coverage to lead to interannual variability there would need to be spatial/temporal variation in the proportions of adult fish in the surveyed area. This could occur if there are spawning migrations, which vary in time or if there is variability in the overall juvenile or adult distribution. There is some evidence for this type of distributional variation in 
the Subarea $2+$ Div. 3KLMNO and Subarea I and II populations (Anon., 1994; Albert et al., 2001). This idea received some support here, in that estimates from data collected over the whole area were less variable compared with estimates from Subareas only. More data sets of this sort with longer time series are required to fully explore this possibility.

Estimates of maturity-at-size and age could be highly variable if macroscopic determination of juvenile and adult stages was difficult and/or unreliable. There have been several comparisons of macroscopically and histologically determined maturity stages (Walsh and Bowering, 1981; Junquera and SaboridoRey, MS 1995b; Junquera et al., 1999; Morin and Bernier, MS 1999). These studies have generally indicated that the largest number of misclassifications of the juvenile stage happen with the early maturing and resting stages. Although these studies concluded that estimates can be improved by histological determination of maturity, most found little difference between estimates from the two methods. A study, which compared macroscopic determination at sea with those conducted in the laboratory, has found differences between the two sets (Gundersen, Møre Research, Norway, unpublished data). Misclassification of adult and juvenile fish would need to be temporally and spatially variable to lead to the variation seen in this study. The accuracy of macroscopic determinations of maturity should be explored further, in particular examining the degree to which misclassification varies across year and cohort.

The maturation and spawning of Greenland halibut has been found to be rather irregular in previous studies. Spawning fish have been found in many areas widely dispersed from the main spawning locations (Riget et al., 1992; Junquera and Zamarro, 1994; Morgan and Bowering, MS 2001). There is also evidence of some spawning outside of a single spawning season with fish often found in spawning condition throughout the year (Federov, 1971; Junquera and Zamarro, 1994; Sigurdsson, MS 1977). This species may also skip spawning or regularly take more than a single year to mature eggs for spawning (Federov, 1971; Junquera et al., MS 2001). This complicated spawning cycle may lead to highly variable distribution of adult and juvenile fish and/or make determination of stage of maturity more difficult. It is possible that data collection spanning the whole year could improve estimates of maturity-at-age and size.

One of the aims of constructing annual estimates of proportion mature is for use in the calculation of spawning stock biomass. The interannual variability exhibited by most of the data sets examined here limits their usefulness for this purpose. Averaging of data across time as well as ways to combine data from different parts of the distribution of a population may be required. However, trends in maturation are common (e.g. Morgan and Colbourne, 1999) and a balance must be struck between limiting interannual variability and averaging over too great a time period that masks real trends in the data. The appropriate means of achieving this balance needs to be examined within the stock assessment process on a case-by-case basis.

\section{Acknowledgements}

We thank the many technical staff and ships crew involved in the collection of these data. P. Shelton provided helpful suggestions for the comparison of variability. G. Cossitt helped in the production of the map. J. Moore and an anonymous reviewer gave helpful comments on the manuscript.

\section{References}

ALBERT, O. T., E. M. NILSSEN, K. H. NEDREAAS, and A. C. GUNDERSEN. 2001. Distribution and abundance of juvenile northeast Arctic Greenland halibut (Reinhardtius hippoglossoides) in relation to survey coverage and the physical environment. ICES J. Mar. Sci., 58: 1053-1062.

ANON. 1994. Northwest Atlantic Fisheries Organization Scientific Council Report 1993. Northwest Atlantic Fisheries Organization, Dartmouth, Nova Scotia, 234 p.

BOJE, J. MS 1994. Migrations of Greenland halibut in the Northwest Atlantic based on tagging experiments in Greenland waters 1986-1992. NAFO SCR Doc., No. 18, Serial No. N2383, 13 p.

BOJE, J. and N. R. HAREIDE. MS 1993. Trial deepwater longline fishery in the Davis Strait, May-June, 1992. NAFO SCR Doc., No. 53, Serial No. N2236, 6 p.

BOWERING, W. R. 1982. Population dynamics of the Greenland halibut in the Gulf of St. Lawrence. J. Northw. Atl. Fish. Sci., 3: 141-147.

1984. Migrations of Greenland halibut, Reinhardtius hippoglossoides, in the Northwest Atlantic from tagging in the Labrador-Newfoundland region. J. Northw. Atl. Fish. Sci., 5: 85-91.

BOWERING, W. R., and W. B. BRODIE. 1995. Greenland halibut (Reinhardtius hippoglossoides). A review of the dynamics of its distribution and fisheries off eastern Canada and Greenland. In: NATO ASI Series Volume XX: Deep water fisheries of the North Atlantic Oceanic slope. A. G. Hopper (ed.). Kluwer Academic Publishers. Netherlands. p. 113-160.

BOWERING, W. R., and K. H. NEDREAAS. 2000. A comparison of Greenland halibut (Reinhardtius hippoglossoides (Walbaum)) fisheries and distribution in the Northwest and Northeast Atlantic. Sarsia, 85: 61-76. 
DE CARDENAS, E., J. M. CASAS, R. ALPOIM, and H. MURUA. MS 1996. Preliminary results of the European longline survey in the NAFO regulatory area. NAFO SCR Doc., No. 34, Serial No. N2709, 6 p.

FEDOROV, K. E. 1968. Oogenesis and sexual cycle of Greenland halibut. Trudy PINRO, 23: 425-451. (In Russian).

FEDOROV, K. Ye. 1971. The state of the gonads of the Barents Sea Greenland halibut [Reinhardtius hippoglossoides (Walb.)] in connection with the failure to spawn. J. Ichth., 11: 673-682.

FOTLAND, A., A. BORGE, H. GJØSÆTER, and H. MJANGER. 1997. Handbook for sampling fish and crustaceans. Institute of Marine Research, Bergen, Norway, 1997. (In Norwegian).

JORGENSEN, O. 1997. Movement patterns of Greenland halibut, Reinhardtius hippoglossoides (Walbaum), at west Greenland, as inferred from trawl survey distribution and size data. J. Northw. Atl. Fish. Sci., 21: 23-37.

MS 1998. Survey for Greenland halibut in NAFO Divisions 1C-1D. NAFO SCR Doc., No. 25, Serial No. $\mathrm{N} 3010,26 \mathrm{p}$.

JORGENSEN, O., and J. BOJE. MS 1994. Sexual maturity of Greenland halibut in NAFO Subarea 1. NAFO SCR Doc., No. 42, Serial No. N2412, 17 p.

JUNQUERA, S. MS 1994. Analysis of the variations in the spatial distribution and spawning of the Greenland halibut in Divisions 3LMN (1990-93). NAFO SCR Doc., No. 25, Serial No. N2391, 12 p.

JUNQUERA, S., and J. ZAMARRO. 1994. Sexual maturity and spawning of Greenland halibut (Reinhardtius hippoglossoides) from Flemish Pass area. NAFO Sci. Coun. Studies, 20: 47-52.

JUNQUERA, S., and F. SABORIDO-REY. MS 1995a. Temporal and spatial variation in length at maturity in $3 \mathrm{LM}$ and 3 NO Greenland halibut. NAFO SCR Doc., No. 29, Serial No. N2538, 6 p.

MS 1995b. Histological assessment of sexual maturity in Greenland halibut in Div. 3LM. NAFO SCR Doc., No. 28, Serial No. N2537, 9 p.

JUNQUERA, S., E. ROMAN, X. PAZ, and G. RAMILO. 1999. Changes in Greenland halibut growth, condition and fecundity in the northwest Atlantic (Flemish Pass, Flemish Cap and southern Grand Bank). J. Northw. Atl. Fish. Sci., 25: 17-28.

JUNQUERA, S., E. ROMAN, J. MORGAN, M. SAINZA, and G. RAMILO. MS 2001. Time scale of ovarian maturation in Greenland halibut. NAFO SCR Doc., No. 124, Serial No. N4512, $11 \mathrm{p}$.

KOVTSOVA, M. V., and G. P. NIZOVTSEV. MS 1985. Peculiarities of growth and maturation of Greenland halibut of the Norwegian-Barents sea stock in 1971-1984. ICES C.M. Doc., No. G:7.

MCCULLAGH, P., and J. A. NELDER. 1983. Generalized Linear Models. Chapman and Hall, London.

MORGAN, M. J., and W. R. BOWERING. 1997. Temporal and geographic variation in maturity at length and age of
Greenland halibut (Reinhardtius hippoglossoides) from the Canadian north-west Atlantic with implications for fisheries management. ICES J. Mar. Sci., 54: 875-885.

MS 1999. Estimates of maturity of Greenland halibut from 'synoptic' surveys. NAFO SCR Doc., No. 9, Serial No. N4056, 11 p.

MS 2001. Further comparisons of estimates of maturity for Greenland halibut from surveys covering different portions of the stock area. NAFO SCR Doc., No. 49, Serial No. N4427, 10 p.

MORGAN, M. J., and E. B. COLBOURNE. 1999. Variation in maturity-at-age and size in three populations of American plaice. ICES J. Mar. Sci., 56 : 673-688.

MORIN, B., and B. BERNIER. MS 1999. Assessment and biology of Greenland halibut (Reinhardtius hippoglossoides) in the Gulf of St. Lawrence (4RST) in 1998. DFO - CSAS Res. Doc., No. 185, 57 p.

NIELSEN, J. G., and J. BOJE. MS 1995. Sexual maturity of Greenland halibut at West Greenland based on visual and histological observations. NAFO SCR Doc., No. 18, Serial No. N 2525, 7 p.

RIGET, F., J. BOJE, and V. SIMONSEN 1992. Analysis of meristic characters and genetic differentiation in Greenland halibut (Reinhardtius hippoglossoides) in the Northwest Atlantic. J. Northw. Atl. Fish. Sci., 12: 7-14.

SAS INSTITUTE INC. 1989. SAS/STAT User's Guide. Cary, NC. SAS Institute Inc.

1993. SAS Technical Report P-243, SAS/STAT Software: The Genmod Procedure, Release 6.09. Cary, NC. SAS Institute Inc.

SIGURDSSON, A. MS 1977. On the spawning grounds of Greenland halibut in Icelandic waters. ICES C.M. Doc., No. F:28, 11 p.

1981. Migrations of Greenland halibut (Reinhardtius hippoglossoides (Walb.)) from Iceland to Norway. Rit Fiskideidar, 6: 3-6.

SMIDT, E. L. B. 1969. The Greenland halibut, Reinhardtius hippoglossoides (Walb.), biology and exploitation in Greenland waters. Medd. Dan. Fisk. Havunders., 6: 79148.

SOROKIN, V. P., and G. V. GRIGORJEV. 1968. Spermatogenesis and sexual cycle of Greenland or black halibut from the Barents sea population. Trudy PINRO 23: 413-423 (in Russian).

TEMPLEMAN, W., V. M. HODDER, and R. WELLS. 1978. Sexual maturity and spawning in haddock, Melanogrammus aeglefinus, of the southern Grand Bank. ICNAF Res. Bull., 13: 53-65.

VIS, M. L., S. M. CARR, W. R. BOWERING, and W. S. DAVIDSON. 1997. Greenland halibut (Reinhardtius hippoglossoides) in the North Atlantic are genetically homgeneous. Can. J. Fish. Aquat. Sci., 54: 1813-1821.

WALSH, S. J., and W. R. BOWERING. 1981. Histological and visual observations on oogenesis and sexual maturity in Greenland halibut off northern Labrador. NAFO Sci. Coun. Studies, 1: 71-75. 